\title{
Glacier change over the last century, Caucasus Mountains, Georgia, observed from old topographical maps, Landsat and ASTER satellite imagery
}

\author{
Levan G. Tielidze \\ Department of Geomorphology, Vakhushti Bagrationi Institute of Geography, Ivane, Javakhishvili Tbilisi State University, \\ 6 Tamarashvili st., 0177 Tbilisi, Georgia \\ Correspondence to: Levan G. Tielidze (levan.tielidze@ tsu.ge)
}

Received: 12 May 2015 - Published in The Cryosphere Discuss.: 17 July 2015

Revised: 29 February 2016 - Accepted: 11 March 2016 - Published: 21 March 2016

\begin{abstract}
Changes in the area and number of glaciers in the Georgian Caucasus Mountains were examined over the last century, by comparing recent Landsat and ASTER images (2014) with older topographical maps (1911, 1960) along with middle and high mountain meteorological stations data. Total glacier area decreased by $8.1 \pm 1.8 \%\left(0.2 \pm 0.04 \% \mathrm{yr}^{-1}\right)$ or by $49.9 \pm 10.6 \mathrm{~km}^{2}$ from $613.6 \pm 9.8 \mathrm{~km}^{2}$ to $563.7 \pm 11.3 \mathrm{~km}^{2}$ during $1911-1960$, while the number of glaciers increased from 515 to 786 . During 1960-2014, the total ice area decreased by $36.9 \pm 2.2 \%\left(0.7 \pm 0.04 \% \mathrm{yr}^{-1}\right)$ or by $207.9 \pm 9.8 \mathrm{~km}^{2}$ from $563.7 \pm 11.3 \mathrm{~km}^{2}$ to $355.8 \pm 8.3 \mathrm{~km}^{2}$, while glacier numbers decreased from 786 to 637 . In total, the area of Georgia glaciers reduced by $42.0 \pm 2.0 \%\left(0.4 \pm 0.02 \% \mathrm{yr}^{-1}\right)$ between 1911 and 2014. The eastern Caucasus section had the highest retreat rate of $67.3 \pm 2.0 \%\left(0.7 \pm 0.02 \% \mathrm{yr}^{-1}\right)$ over this period, while the central part of Georgian Caucasus had the lowest, $34.6 \pm 1.8 \% \quad\left(0.3 \pm 0.01 \% \mathrm{yr}^{-1}\right)$, with the western Caucasus intermediate at $42.8 \pm 2.7 \%$ $\left(0.4 \pm 0.03 \% \mathrm{yr}^{-1}\right)$.
\end{abstract}

\section{Introduction}

Alpine glaciers are an important component of the global hydrologic cycle. Glaciers can help to regulate streamflow in regions where water is stored during colder periods of the year and later released as melt water runoff during warm dry conditions (Beniston, 2003; Earl and Gardner, 2016). Alpine glaciers also provide proxy information on regional and global climate where other long-term records may not exist, as changes in glacier mass and/or extent can reflect changes in temperature and/or precipitation (e.g. Oerlemans and Fortuin, 1992; Meier et al., 2007). Regular and detailed observations of alpine glacier behaviour are necessary in regions such as the Georgian Caucasus, where the glaciers are an important source of water for agricultural production, and runoff in large glacially fed rivers (Kodori, Enguri, Rioni, Tskhenistskali, Nenskra) supply hydroelectric power stations. In addition, glacier outburst floods and related debris flows are a significant hazard in Georgia and in the Caucasus. Thus, future trends in glacier change are of considerable interest to the region.

The study of glaciers in the Caucasus began in the first quarter of the 18th century, in the works of Georgian scientist Vakhushti Bagrationi, followed by foreign scientists a century later. e.g. W. Abich, D. Freshfield, G. Radde, N. Dinik, I. Rashevskiy, A. Reinhardt. Data on the glaciers of Georgia are found in the catalog of the Caucasus glaciers compiled by Podozerskiy (1911). Subsequently, in the 1960s large-scale (1:50 000) topographic maps were published and compiled from aerial photographs taken 1955-1960. Based on these maps, Gobejishvili $(1989,1995)$ documented further statistical information about the glaciers of Georgia. The glacier inventory of the former USSR was published in 1975, where data on the glaciers of Georgia were obtained from (19551957) aerial images. Thus, complete statistical information on the glaciers of Georgia has not been published for about 50 years.

While the glaciers of the Caucasus are much larger than those of the Middle East, the Randolph Glacier Inven- 


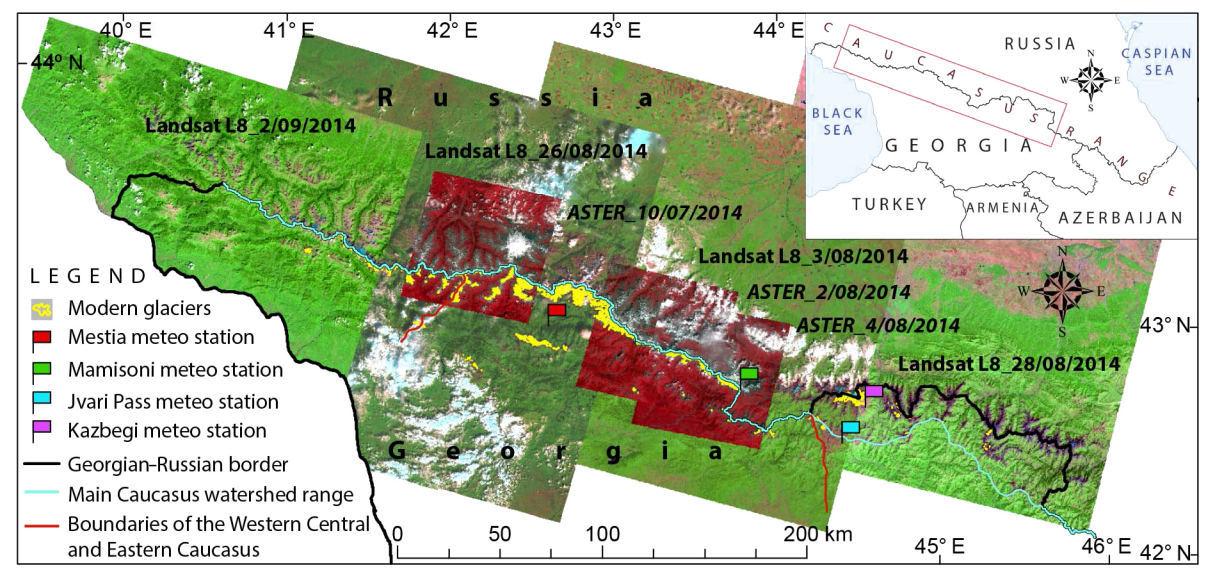

Figure 1. Georgian Caucasus glacier outlines (in yellow) derived from Landsat and ASTER imagery, and Georgia's mountain meteorological station locations.

tory (RGI), presents these together as one main region (Pfeffer et al., 2014). In the RGI version 3.2, the Greater Caucasus region database contains 1303 glaciers, with a total area of $1100.7 \mathrm{~km}^{2}$. Although this version omitted glaciers in the eastern Caucasus section (Shahgedanova et al., 2014), these omissions have been partly rectified by adding nominal glaciers from the WGI-XF (Cogley, 2009). The 339 added glaciers, with date ranges $1965-1976$, cover $155 \mathrm{~km}^{2}$ and include some in the central Caucasus section (in the Svaneti and Lechkhumi sub-ranges in the Georgian Caucasus) and in the Lesser Caucasus in Armenia (Arendt et al., 2015). After these corrections, the RGI 4.0 and 5.0 version databases contain 1637 glaciers, with a total area of $1255.6 \mathrm{~km}^{2}$. The GLIMS database (http://www.glims.org) identifies (based on 2005-2007 ASTER imagery) in excess of 1300 glaciers with a combined area of $1354 \mathrm{~km}^{2}$. These previous inventories, executed by semi-automatic digitizing also do not consider the separate Georgian Caucasus glaciers composition.

Most recent studies of the Caucasus have focused on the northern slopes of the range in Russia which contain limited information about Georgian glaciers. For example, Stokes et al. (2006) examined changes in termini positions of 113 glaciers in the central Caucasus between 1985 and 2000 using Landsat imagery. From this assessment, they reported a total loss of bare ice area of about $10 \%$. Shahgedanova et al. (2014) examined two objectives: (i) to quantify changes in glacier area in the central and western sectors of the Caucasus Mountains between 1999 and 2001 and between 2010 and 2012 using ASTER and panchromatic Landsat imagery; and (ii) to assess changes in glacier retreat rates from 1987-2010 using aerial photographs and ASTER imagery for a sub-sample of valley glaciers. From this assessment (total 498 glaciers), they inferred a total loss of ice area of $4.7 \pm 2.1 \%$ or $19.2 \pm 8.7 \mathrm{~km}^{2}$ from $407.3 \pm 5.4 \mathrm{~km}^{2}$ to $388.1 \pm 5.2 \mathrm{~km}^{2}$.

Recent published works about glaciers on the south-facing slopes of the Caucasus, have examined changes in glacier area for river basins in the Georgian Caucasus between 1911 and 2014 using old topographical maps and modern aerial images. These studies inferred a total loss of ice area $\sim 30.1 \%$ (from 48.5 to $33.9 \mathrm{~km}^{2}$ ) in Dolra River basin (Tielidze et al., 2015a), $\sim 38.8 \%$ (from 100.0 to $\sim 61.2 \mathrm{~km}^{2}$ ) in Mulkhura River basin (Tielidze et al., 2015b); and $\sim 20.1 \%$ (from 55.2 to $44.1 \mathrm{~km}^{2}$ ) in Mestiachala River basin (Tielidze et al., 2015c).

This article presents the percentage and quantitative changes in the number and area of glaciers for all Georgian Caucasus in the years 1911-1960-2014, by individual river basins.

\section{Study area}

The Greater Caucasus mountain range extends along the northern territory of Georgia for about $750 \mathrm{~km}$. The northern slopes and watersheds of the Caucasus contain more glaciers than the southern slopes, due to higher relief and extremely partitioned slopes, gorges and cirque depressions, associated with the Würm Pleistocene period. The Georgian glaciers are concentrated mostly in the southern watersheds, as well as in the sub-ranges of the Greater Caucasus and Kazbegi massif (Tielidze, 2016). According to morphological and morphometric characteristics, the Greater Caucasus can be divided into three parts within Georgia - the western, central and eastern Caucasus (Maruashvili, 1971; Gobejishvli, 1995) (Fig. 1).

The western Caucasus is located to the west of the Dalari Pass, and includes four main sub-ranges: Gagra, Bzipi, Chkhalta (Abkhazeti) and Kodori. These are lower in elevation than the central and eastern Caucasus, with just one peak (Dombai-ulgen) exceeding $4000 \mathrm{~m}$ and several peaks between 3800 and $4000 \mathrm{~m}$. However the western section receives more abundant precipitation than the central and eastern Caucasus. 
The central Caucasus is the highest in elevation and the main centre of glaciation in the Caucasus. Its western boundary is Dalari Pass and runs along the Enguri and Kodori rivers' watersheds (Kharikhra range), while its east boundary coincides with the Jvari Pass and then runs along the bottom of the river gorges of Tergi-Bidara and Mtiuleti's Aragvi (Maruashvili, 1971). In terms of the glacier distribution, orographic units can be distinguished in the central Caucasus: Svaneti, Samegrelo, Lechkhumi, Shoda-Kedela and Java ranges.

The eastern Caucasus is located to the east of the Georgian Military Road (Jvari Pass). Both the southern and northern slopes of the Caucasus range lie within Georgia's boundaries. The eastern Caucasus has the high average elevation with many peaks e.g. Kuro, Komito, Shani, Amgha, Tebulosmta, exceeding $4000 \mathrm{~m}$. However, because of the relatively dry climate and geomorphological features, there are fewer glaciers in the eastern Caucasus than in the lower western Caucasus.

The location of the Equilibrium Line Altitude (ELA) for the river basins in the Georgian Caucasus was first determined by A. Reinhardt (1916) based on the 1880-1910 topographical maps (1:40000 scale) and field-desk research. He determined ELA in 17 main and tributary river basins, with ELA mean elevation at $3090 \mathrm{~m}$ a.s.l. Using the 19551960 original aerial imagery, 1:50000 scale topographical maps (1960) and several years of field-desk research, R. Gobejishvili (1995) calculated the ELA (1960) in 10 main and 18 tributary river basins at $\sim 3260 \mathrm{~m}$ a.s.1., with the highest ELA values ( $3500 \mathrm{~m}$ a.s.1.) in the river basins of the eastern Georgian Caucasus, where there is lower annual snow precipitation.

The Caucasus Mountains are characterized by strong longitudinal gradients that produce a maritime climate in the west and more continental climate in the east. The westernmost areas typically receive around three to four times more precipitation than eastern areas (Horvath and Field, 1975). The southern slopes also experience higher temperatures and precipitation, which can be up to $3000-4000 \mathrm{~mm}$ annually in the southwest (Volodicheva, 2002). Much of this precipitation falls as snow, especially on windward slopes of the western Greater Caucasus, which are subjected to moist air masses from the Black Sea (Stokes, 2011).

January is usually the coldest month in Georgia, but in the high mountain regions $(2700-2800 \mathrm{~m})$ February is often the coldest month. Stable frosty periods at a height of 2000-3000 m last from November to May, and above $3000 \mathrm{~m}$ from October to July. The average January temperature is $-8^{\circ} \mathrm{C}$ at a height of $2000 \mathrm{~m}$ and the coldest month is $-16^{\circ} \mathrm{C}$ at a height of $3600 \mathrm{~m}$ (Gobejishvili, 1995). The average monthly temperature of the warmest month - August, varies from +14 to $+17^{\circ} \mathrm{C}$ at about $1500 \mathrm{~m}$ of altitude, falling to +7.6 and $+3.4^{\circ} \mathrm{C}$, respectively, at 2800 and $3600 \mathrm{~m}$ (Gobejishvili, 1995). Average multiannual air temperature ranges from $+5.9^{\circ} \mathrm{C}$ (Mestia, $1906-2013$ ) to $-5.7^{\circ} \mathrm{C}$ (Kazbegi, 1907-2009).

The snow cover is unevenly distributed in the Greater Caucasus Range; snowfall in the western Caucasus is greater and snow cover lasts for a longer period than in the eastern Caucasus. The average snow cover in the eastern Caucasus is $\sim 110$ days at $\sim 1500 \mathrm{~m}$ a.s.l., $\sim 145$ days at $\sim 2000 \mathrm{~m}$ a.s.l. and $\sim 195$ days at $\sim 2500 \mathrm{~m}$ a.s.l. In the western Caucasus snow cover extends for $\sim 135,182$ and 222 days, respectively. In the eastern Caucasus the average depth of snow cover is $\sim 21-40 \mathrm{~cm}$ at $\sim 1500-2000 \mathrm{~m}$ elevation, and more than $100 \mathrm{~cm}$ at $\sim 2000-2500 \mathrm{~m}$ (Gobejishvili, 1995; Tielidze, 2016).

\section{Data sources and methods}

\subsection{Old topographical maps}

The compilation of the first reliable map of the Caucasus, at a scale of 1:420000 and depicting the largest glaciers, was completed by 1862 . Topographic surveys of the Caucasus at a scale of 1:42000 were accomplished 50 years later (1880-1910). Having analyzed these maps, Podozerskiy (1911) published the first inventory of Caucasus glaciers (Kotlyakov et al., 2010). Detailed analysis of these early data showed some defects in the shape of the glaciers and in particular the inaccessible valley glaciers were depicted incorrectly. This caused some error in the identification of precise areas, such as in the Enguri and Rioni River basins, which were difficult to access for plane table surveying. However as no other data exist from this time, these maps are the most reliable source for this research to establish century-long trend glacier changes (Tielidze et al., 2015c).

The oldest topographic maps were replaced in 1960, under the former Soviet Union with 1:50000 scale topographical maps from 1955 to 1960 aerial images. Based on these, Gobejishvili (1989) generated new statistical information on the glaciers of Georgia.

The next inventory of the Caucasus glaciers was the result of a manual evaluation of selected glacier parameters from the original aerial photographs and topographic maps (Cata$\log$ of Glaciers of the USSR, 1975; Khromova et al., 2014), where information on Georgia was obtained from the same (1955-1957) aerial photographs. There are some mistakes in the catalog regarding number and area of the glaciers in some river basins (particularly the Bzipi, Kelasuri, Khobisckali, Liakhvi, Aragvi and Tergi), where temporary snow fields were considered as glaciers (Gobejishvili, 1995). The USSR catalog data sets contain tables with glacier parameters but not glacier outlines. As the USSR and Gobejishvili's inventories were based on the same aerial photographs, I have used both data sets in this article for a more comprehensive comparison. 
As this information was only available in printed form, I scanned and co-registered the maps and images using the 3 August 2014 Landsat image as a master. Offsets between the images and the archival maps were within one pixel $(15 \mathrm{~m})$ based on an analysis of common features identifiable in each data set. I re-projected both maps $(1911,1960)$ to Universal Transverse Mercator (UTM), zone 38-north on the WGS84 ellipsoid, to facilitate comparison with modern image data sets (ArcGIS 10.2.1 software).

\subsection{Landsat and ASTER imagery and glacier area mapping}

Many of the world's glaciers are in remote areas, such that land-based methods of measuring their changes are expensive and labour-intensive. Remote sensing technologies have offered a solution to this problem (Kaab, 2002). Satellite imagery-Landsat L8 OLI (Operational Land Imager), since February 2013, and Advanced Spaceborne Thermal Emission and Reflection Radiometer (ASTER), since January 2000 , with $15 / 30 \mathrm{~m}$ resolution provide convenient tools for glacier analysis. Together with old topographical maps, these allow us to identify changes in the number and area of glaciers over the last century. Most of the images (Landsat and ASTER) were acquired at the end of the ablation season, from 2 August to 2 September (except for one ASTER image, on 10 July), when glacier tongues were free of seasonal snow under cloud-free conditions and suited for glacier mapping (Fig. 1), but with some glacier margins obscured by shadows from rock faces and glacier cirque walls (Khromova et al., 2014). Landsat (level L1T) georeferenced images were supplied by the US Geological Survey's Earth Resources Observation and Science (EROS) Center and downloaded using the EarthExplorer tool (http://earthexplorer.usgs.gov/). ASTER (level L1T) images were supplied by the National Aeronautic and Space Administration's (NASA) Earth Observing System Data and Information System (EOSDIS) and downloaded using the Reverb/ECHO tool (http://reverb. echo.nasa.gov/).

I used the Landsat 8 panchromatic band, along with a colour-composite scene for each acquisition date, for Landsat images - bands 7 (short-wave infrared), 5 (near infrared) and 3 (green); for ASTER images - bands 3 (near-infrared), 2 (red) and 1 (green). Each glacier boundary was manually digitized and the total surface area for each glacier calculated according to Paul et al. (2009). The size of the smallest glacier mapped was $0.01 \mathrm{~km}^{2}$.

\subsection{Glacier delineation error and analysis}

For the Georgian Caucasus glaciers I calculated three error terms resulting from (a) co-registration of old maps and satellite images, (b) glacier area error and (c) debris cover assessment. a. Offsets between the images and archival maps are within 1 image pixel $(15 \mathrm{~m})$. Glacier outlines on the old topographic maps $(1911,1960)$ correspond to a line thickness of $12 \mathrm{~m}(1: 42000)$ and $15 \mathrm{~m}(1: 50000)$. Using the buffer method from Granshaw and Fountain (2006), these yield a total potential error of $\pm 1.64 \%$.

b. The glacier area error is mostly inversely proportional to the length of the glacier margin (Pfeffer et al., 2014). Applying glacier buffers account for the length of the glacier perimeter, while the buffer width, is critical to the resultant glacier area error (Guo et al., 2015). I estimated uncertainty by the buffer method suggested by Bolch et al. (2010) and Granshaw and Fountain (2006) with a buffer size $7.5 \mathrm{~m}$ for all aerial images and maps, based on the $15 \mathrm{~m}$ image pixel size, and map uncertainty in the absence of stated historical accuracies. This generated an average uncertainty of the mapped glacier area of $2.3 \%$ for 2014 (satellite images), $2.0 \%$ for 1960 (topographical maps) and $1.6 \%$ for 1911 (Podozerskiy catalog).

c. Manual digitizing by an experienced analyst is usually more accurate than automated methods for glaciers with debris cover (Raup et al., 2007), which is a major source of error in glacier mapping (Bhambri et al., 2011; Bolch et al., 2008) In the Caucasus, supra-glacial debris cover has a smaller extent than in many glacierized regions, especially Asia (Stokes et al., 2007; Shahgedanova et al., 2014). One of the most heavily debris-covered glaciers in the Georgian Caucasus is Khalde Glacier $\left(42.596^{\circ} \mathrm{N}, 43.22^{\circ} \mathrm{E}\right)$ where supra-glacial debris covers $23 \%$. For the precise determination of debris cover I also used my GPS field data collected in most glaciated areas during 2004-2014, including those with highest debris cover (Khalde, Lekhziri, Chalaati, Shkhara, Devdoraki, Zopkhito, Ushba, Buba and Gergeti). Thus the error associated with debris-covered glaciers was considered to be negligible.

\subsection{Climatic data}

I examined the average monthly and mean annual air temperature records, along with accumulation season (OctoberApril) precipitation from middle and high mountain meteorological stations of Georgia to characterize climatic variations since 1907 (see Fig. 1 for their locations): Mestia (1441 m a.s.1.); Mamisoni (2854 m a.s.1.), Jvari Pass (2395 m a.s.l.) and Kazbegi (3653 m a.s.l.).

The primary goal was to assess long-term temperature and precipitation variability for association with glacier area change. As high-quality homogenization and in-depth analysis is an extended labour-intensive process (Begert et al., 2005), I relied on the Mann-Kendall test in Addinsoft's XL- 
STAT 2015 for the significance of air temperature and precipitation trends.

\section{Results}

\subsection{Area and number change}

The total ice area loss between 1911 and 1960 was $8.1 \pm 1.8 \%$ or $49.9 \pm 10.6 \mathrm{~km}^{2}$, reduced from $613.6 \pm 9.8 \mathrm{~km}^{2}$ to $563.7 \pm 11.3 \mathrm{~km}^{2}$, while the number of glaciers increased from 515 to 786 . These results reflect that in the early 20th century, compound-valley glaciers exceeded $200 \mathrm{~km}^{2}$ (Tielidze, 2014), and these degraded into relatively smaller simple valley glaciers and even smaller cirque glaciers.

Between 1960 and 2014, glacier area decreased by $36.9 \pm 2.2 \%$ or $207.9 \pm 9.8 \mathrm{~km}^{2}$, from $563.7 \pm 11.3 \mathrm{~km}^{2}$ to $355.8 \pm 8.3 \mathrm{~km}^{2}$ and glacier numbers from 786 to 637 . These occurred because in the 1960-70s, many glaciers were small cirque glaciers, which disappeared completely in the last half century (Tielidze, 2014). Glacier changes according to divisions of the Caucasus range and river basins are described below.

\subsubsection{The western Caucasus}

The Bzipi River gorge is the westernmost basin in Georgia containing glaciers, generally small cirque glaciers about $0.5 \mathrm{~km}^{2}$ in area, (Tielidze, 2014) with glaciers also in the basins of the Kelasuri and Kodori rivers.

Podozerskiy (1911) indicates there were 10 glaciers in the Bzipi basin with an area of $4.0 \pm 0.01 \mathrm{~km}^{2}$. From the 1960 maps there were 18 glaciers with an area of $9.9 \pm 0.2 \mathrm{~km}^{2}$; the satellite images of 2014 also showed 18 glaciers, but with a reduced area $4.0 \pm 0.1 \mathrm{~km}^{2}$ (Table 1).

Podozerskiy does not provide any information on the Kelasuri River basin. In 1960 there was only one glacier mapped with an area of $0.3 \pm 0.02 \mathrm{~km}^{2}$, and similarly in 2014 with an area of $0.1 \pm 0.01 \mathrm{~km}^{2}$ (Table 1).

The majority of contemporary glaciers on the southern slopes of the western Caucasus are located in the Kodori River basin, which extends from the Marukhi Pass to the Dalari Pass, including several peaks between 3800 and $4000 \mathrm{~m}$. The 1911 data indicate 118 glaciers in the Kodori River basin with an area of $73.2 \pm 1.6 \mathrm{~km}^{2}$. In 1960, 160 glaciers were mapped with an area of $63.7 \pm 1.6 \mathrm{~km}^{2}$ and in 2014 there were 145 glaciers in this basin with a total area of $40.1 \pm 1.3 \mathrm{~km}^{2}$ (Table 1 ).

In total, in the western Caucasus, glacier area decreased by $4.3 \pm 2.3 \%$ or by $3.3 \pm 1.7 \mathrm{~km}^{2}$ in $1911-1960$. Between 1960 and 2014, glacier area was reduced by $40.2 \pm 2.3 \%$ or by $29.7 \pm 1.6 \mathrm{~km}^{2}$ (Table 2 ).

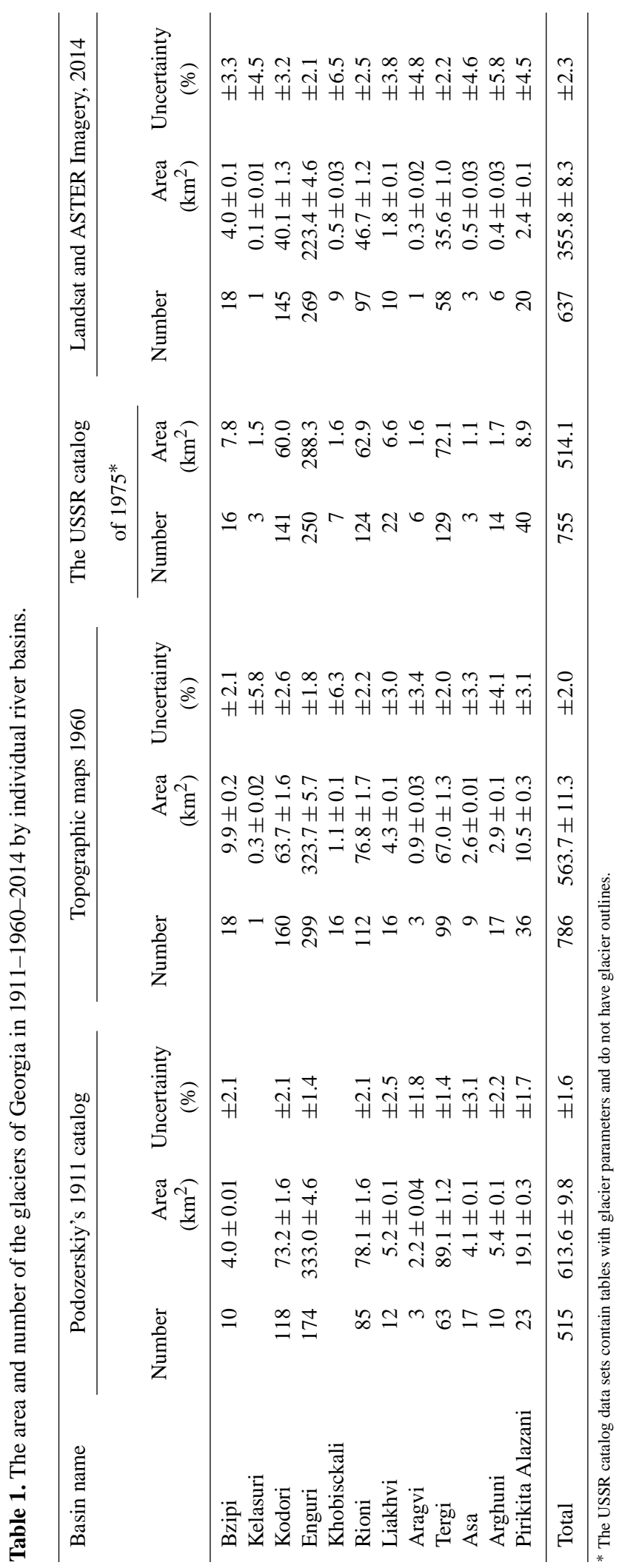




\subsubsection{The central Caucasus}

The central Caucasus section is distinguished by the highest relief in Georgia, where five peaks exceed $5000 \mathrm{~m}$. River basins include the Enguri, Khobistskali, Rioni and Liakhvi.

The Enguri River basin has the largest number and area of contemporary glaciers exceeding all other basins combined. These include the largest glaciers in Georgia such as the Lekhziri, southern and northern Tsaneri (Tielidze et al., 2015b, c). In 1911 there were 174 glaciers in the Enguri River basin with a total area of $333.0 \pm 4.6 \mathrm{~km}^{2}$; in 1960 , 299 glaciers were mapped with an area of $323.7 \pm 5.7 \mathrm{~km}^{2}$, and in 2014 there are 269 glaciers with a total area of $223.4 \pm 4.6 \mathrm{~km}^{2}$ (Table 1).

No information is available about the glaciers of the Khobistskali River basin in the catalog of Podozerskiy, but in 1960, there were 16 glaciers with a total area of $1.1 \pm 0.1 \mathrm{~km}^{2}$ and in 2014 , nine glaciers had an area of $0.5 \pm 0.03 \mathrm{~km}^{2}$ (Table 1).

Another important center of glaciation in Georgia is the Rioni River basin with peaks above $4000 \mathrm{~m}$. On the southern slope of the Caucasus, the Rioni River basin is third behind the Enguri and Kodori River basins in the number of contemporary glaciers, and in area it is only behind the Enguri River basin. In 1911 there were 85 glaciers in the Rioni River basin with an area of $78.1 \pm 1.6 \mathrm{~km}^{2}$. In 1960 the number of glaciers was 112 with a total area $76.8 \pm 1.7 \mathrm{~km}^{2}$. By 2014 there were 97 glaciers with a total area of $46.7 \pm 1.2 \mathrm{~km}^{2}$ (Table 1). The largest glacier in the Rioni River basin is Kirtisho with an area of $4.4 \pm 0.1 \mathrm{~km}^{2}$.

The Liakhvi River basin, is the easternmost basin of the central Caucasus. In 1911 there were 12 glaciers in the basin with an area of $5.2 \pm 0.1 \mathrm{~km}^{2}$, increasing to 16 in 1960 with a total area of $4.3 \pm 0.1 \mathrm{~km}^{2}$. In 201410 glaciers had a total area of $1.8 \pm 0.1 \mathrm{~km}^{2}$ (Table 1).

In total, the glacier area decreased by $2.5 \pm 1.7 \%$ or $10.4 \pm 7.0 \mathrm{~km}^{2}$ in 1911-1960 in the central Caucasus. Between 1960 and 2014, glacier area was reduced by $32.9 \pm 2.0 \%$ or $133.5 \pm 4.9 \mathrm{~km}^{2}$ (Table 2).

\subsubsection{The eastern Caucasus}

In Georgia, the eastern Caucasus is represented both by some southern and the majority northern slopes, in the basins of the Aragvi, Tergi, Asa, Arghuni and Pirikita Alazani rivers.

The westernmost basin of the eastern Caucasus, is the Aragvi River basin. In 1911 there were three glaciers with a total area of $2.2 \pm 0.04 \mathrm{~km}^{2}$, reduced in 1960 to $0.9 \pm 0.03 \mathrm{~km}^{2}$. By 2014 only one glacier (Abudelauri) remained in the basin with an area of $0.3 \pm 0.02 \mathrm{~km}^{2}$ (Table 1).

The Tergi River basin is the main glaciation center of the eastern Caucasus with several peaks above $4500 \mathrm{~m}$ and one above $5000 \mathrm{~m}$ (Mkinvartsveri/Kazbegi). The number and area of glaciers in the Tergi River basin are below only Enguri, Kodori and Rioni with $\sim 9.1 \%$ of the total number of

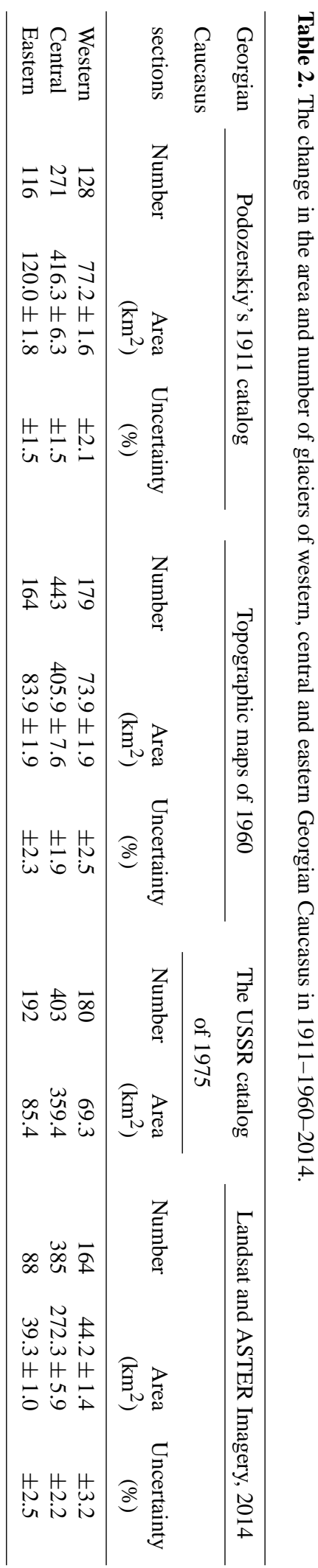




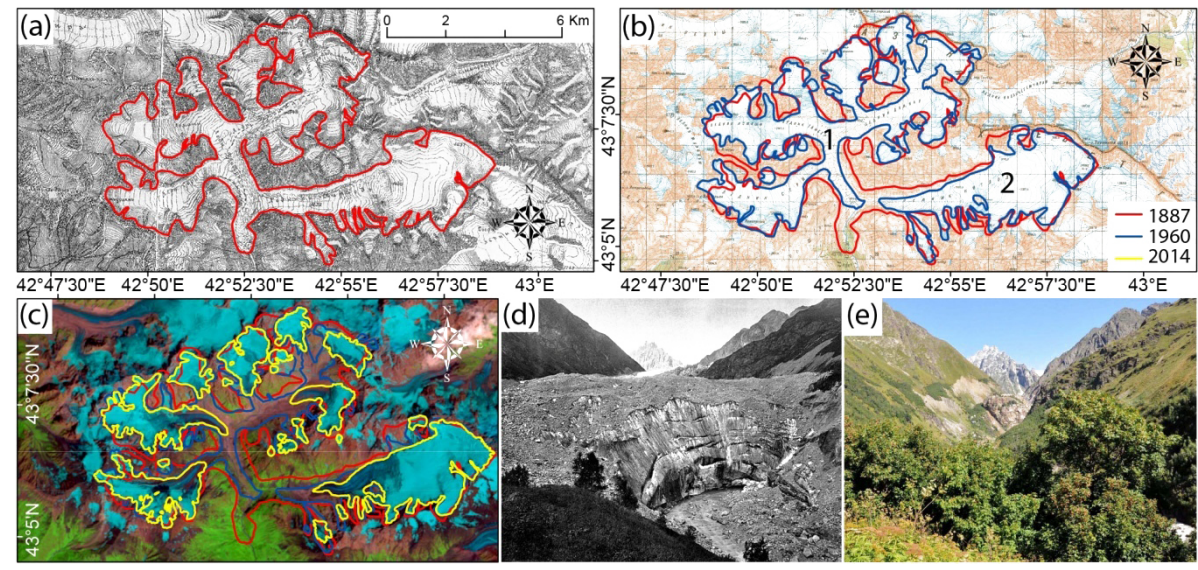

Figure 2. (a) Tviberi Glacier, topographical map 1887; (b) topographical map 1960, 1: Tviberi Glacier, 2: Kvitlodi Glacier; (c) Landsat L8 imagery; (d) Tviberi Glacier terminus in 1884 (photo by M. V. Dechy); (e) the same view in 2011 (photo by L. G. Tielidze).

the glaciers of Georgia, and $10 \%$ by area. In 1911 there were 63 glaciers in the Tergi River basin with a total area of $89.1 \pm 1.2 \mathrm{~km}^{2}$. By 1960 there were 99 glaciers with a total area of $67.0 \pm 1.3 \mathrm{~km}^{2}$, and in 2014 there were 58 glaciers with a total area of $35.6 \pm 1.0 \mathrm{~km}^{2}$ (Table 1). The largest glacier in the Tergi River basin is eastern Suatisi, with an area of $7.7 \pm 0.1 \mathrm{~km}^{2}$.

The Asa River basin is located on the northern slopes of the Greater Caucasus, with peaks above $3700 \mathrm{~m}$. In 1911 there were 17 glaciers with a total area of $4.1 \pm 0.1 \mathrm{~km}^{2}$. By 1960 there were nine glaciers with a total area of $2.6 \pm 0.01 \mathrm{~km}^{2}$ and in 2014 three glaciers with a total area of $0.5 \pm 0.03 \mathrm{~km}^{2}$ (Table 1).

The Arghuni River basin is also located on the northern slope of the Greater Caucasus. In 1911 there were 10 glaciers in the Arghuni River basin with a total area of $5.4 \pm 0.1 \mathrm{~km}^{2}$. By 1960 there were 17 glaciers with a total area of $2.9 \pm 0.1 \mathrm{~km}^{2}$ but in 2014 there were only six glaciers with a total area of $0.4 \pm 0.03 \mathrm{~km}^{2}$ (Table 1).

In 1911 the Pirikita Alazani River basin contained 23 glaciers with a total area of $19.1 \pm 0.3 \mathrm{~km}^{2}$. By 1960 the glaciers were reduced in size and although the number increased to 36 , their area was reduced to $10.5 \pm 0.3 \mathrm{~km}^{2}$. In 2014 there were 20 glaciers in this basin with a total area of $2.4 \pm 0.1 \mathrm{~km}^{2}$ (Table 1).

In total, the glacier area decreased by $30.1 \pm 1.9 \%$ or $36.1 \pm 1.9 \mathrm{~km}^{2}$ in $1911-1960$ in the eastern Caucasus. Between 1960 and 2014, glacier area was reduced by $53.2 \pm 2.4 \%$ or $44.6 \pm 1.4 \mathrm{~km}^{2}$ (Table 2 ).

\subsubsection{The largest glaciers}

The largest glacier at the end of the 19th century and early 20th century in Georgia was Tviberi Glacier (Fig. 2a). According to the topographical map of 1887 the glacier area was $49.0 \pm 0.4 \mathrm{~km}^{2}$ terminating at a height of $2030 \mathrm{~m}$ a.s.l. Before 1960, the Kvitoldi glacier separated from the Tviberi
Glacier's east side, and became an independent glacier (Fig. 2b). In the 1960 topographical map the area of the Tviberi was $24.7 \pm 0.4 \mathrm{~km}^{2}$ and the glacier tongue ended at $2140 \mathrm{~m}$ a.s.l. (Fig. 2b). The Landsat 2014 image shows the Tviberi degradation after 1960, when the smaller simple valley glaciers and even smaller cirque glaciers developed (Tielidze et al., 2015b) (Fig. 2c). Tviberi Glacier degradation is evident in the photographic images of 1884-2011 (Fig. 2d and e).

The compound-valley glacier Tsaneri (with the Nageba Glacier) was the second largest glacier in Georgia according to the topographical map of 1887 with an area of $48.9 \pm 0.5 \mathrm{~km}^{2}$ (Fig. 3). In 1960, the Tsaneri Glacier was still the compound-valley type glacier (without the Nageba Glacier) and its area was $28.3 \pm 0.3 \mathrm{~km}^{2}$ (Tielidze et al., 2015b) (Fig. 3b). The glacier is now in the form of two disconnected glaciers - northern Tsaneri and southern Tsaneri (Fig. 3c-e).

The third largest glacier in Georgia at the end of the 19th century was Lekhziri Glacier with an area of $40.8 \pm 0.3 \mathrm{~km}^{2}$. Lekhziri was a compound-valley glacier at this time (cross-shaped) terminating at a height of $1730 \mathrm{~m}$ a.s.l. (Fig. 4a). In 1960 the glacier area was $36.0 \pm 0.4 \mathrm{~km}^{2}$ terminating at $1970 \mathrm{~m}$ a.s.l. (Fig. 4b). This area reduction was mainly caused by the shortening of its tongue (Tielidze et al., 2015c). Visual observation during an expedition to the glacier in 2011, showed that the central flow of the glacier had weak contact with the two main flows and on the Landsat 2014 image this contact split. This resulted in the northern Lekhziri (central flow) Glacier $\left(6.3 \pm 0.1 \mathrm{~km}^{2}\right)$ and Lekhziri Glacier (consisting of two flows) forming the largest glacier in Georgia (compound-valley type) (Fig. 4c). In 2014 the area of the Lekhziri Glacier was $23.3 \pm 0.4 \mathrm{~km}^{2}$ terminating at $2320 \mathrm{~m}$ a.s.l. Glacier degradation is clearly visible in the photographic images of 1960-2011 (Fig. 4d and e). The second largest glacier in Georgia is the south- 

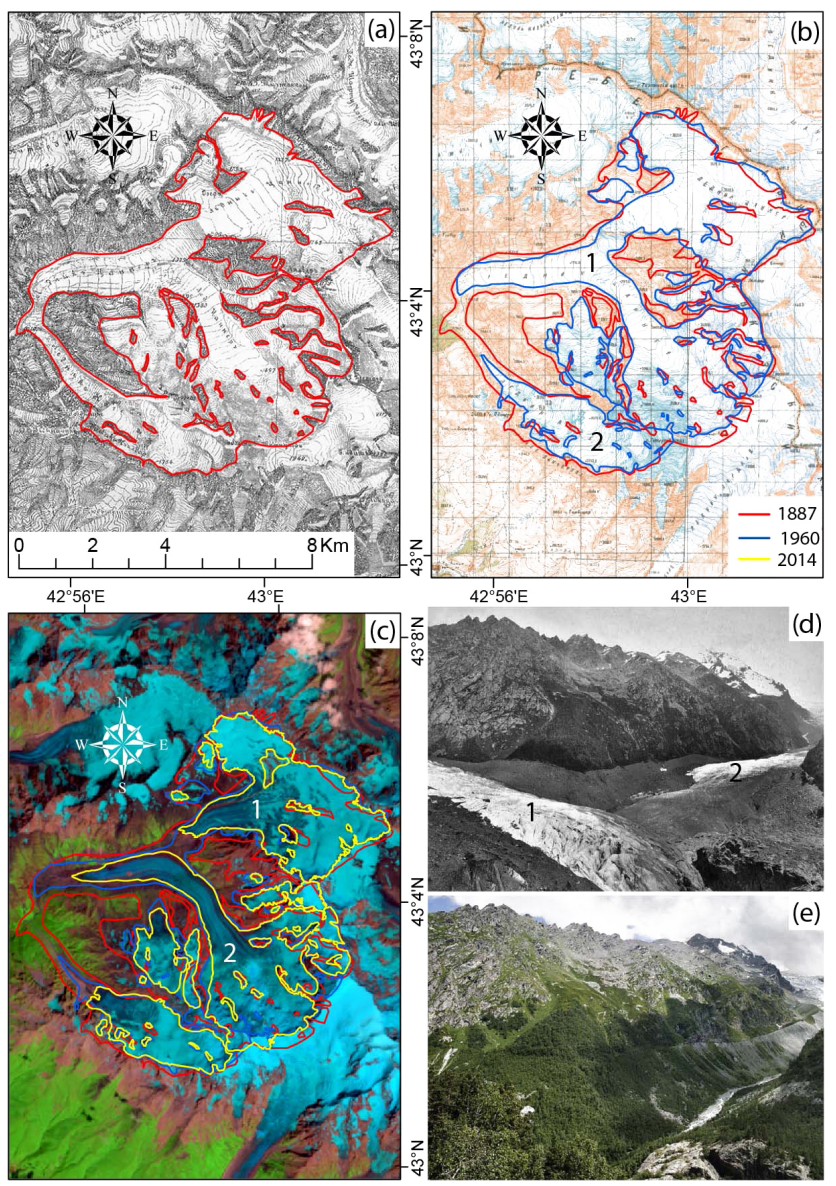

Figure 3. (a) Tsaneri Glacier, topographical map 1887; (b) topographical map 1960, 1 Tsaneri Glacier, 2 Nageba Glacier; (c) Landsat L8 imagery, 1 northern Tsaneri Glacier, 2 southern Tsaneri Glacier; (d) 1 Tsaneri and 2 Nageba glaciers confluence in 1884 (photo by M. V. Dechy); (e) the same view in 2011 (photo by F. Ventura).

ern Tsaneri (Fig. 3c) with area $12.6 \pm 0.2 \mathrm{~km}^{2}$, ahead of the northern Tsaneri (Fig. 3c) third with $11.5 \pm 0.1 \mathrm{~km}^{2}$.

\subsubsection{Glacier morphology, aspect and terminus position}

Valley glaciers cover the largest area $-161.6 \pm 2.7 \mathrm{~km}^{2}$ (69 glaciers, mean area $2.3 \mathrm{~km}^{2}$ ) in Georgia. The second and the third most common are compound-valley (seven glaciers covering $55.0 \pm 1.7 \mathrm{~km}^{2}$, mean area $7.9 \mathrm{~km}^{2}$ ) and cirque types ( 289 glaciers with a total area of $40.9 \pm 1.8 \mathrm{~km}^{2}$, mean area $0.14 \mathrm{~km}^{2}$ ). Cirque glaciers are the most numerous, followed by hanging glaciers (123 covering $16.4 \pm 0.8 \mathrm{~km}^{2}$ ) and cirque-valley glaciers (74 with an area of $4.9 \pm 0.1 \mathrm{~km}^{2}$ ).

Glaciers with south and southwest aspects are the most extensive, covering $72.8 \pm 1.6 \mathrm{~km}^{2}$ (104 glaciers) - and $72.4 \pm 1.4 \mathrm{~km}^{2}$ (71 glaciers), respectively, and combining for $41 \%$ of all glaciers. In contrast, those facing north, northeast and east account for only $22.5 \%$ of the total. These reflect the geographic location of Georgia relative to the Caucasus Mountains.

The terminus positions of the morphological glacier types generally increase in elevation from west to east in the Georgian Caucasus. The compound-valley glacier of Chalaati $\left(43.7^{\circ} \mathrm{N}, 42.42^{\circ} \mathrm{E}\right)$ has the lowest terminus position for the whole Caucasus region (1960 m a.s.l.), based on a 2014 GPS survey. Overall, the valley glacier terminus positions are between 2200 and $3000 \mathrm{~m}$ a.s.l., while cirque and hanging glaciers are at the highest elevations, between 2800 and $3600 \mathrm{~m}$ a.s.l.

\subsection{Climatic variability}

Commencing with the highest elevation station, mean annual air temperatures at the Kazbegi weather station show a slight positive trend in the years $1907-2009$, rising by $0.2{ }^{\circ} \mathrm{C}$ from 1907-1960 to 1961-2009 (Fig. 5). The same is seen in the mean monthly temperature data for all 12 months (Table 3). The Jvari Pass weather station has the highest increase $\left(0.3^{\circ} \mathrm{C}\right)$ in mean annual air temperatures from $1907-1960$ to 1961-2009 although it is not consistent for every month (Table 3). The Mann-Kendall statistical test, indicates a positive trend of mean annual temperature was detected for the whole observed period (1907-2009), and also for 1907-1960, and 1961-2009, for both the Kazbegi and Jvari Pass weather stations (Table 4).

The Mamisoni station shows no significant trend for 19071995 (Fig. 5) and monthly means are cooler between March and August (Table 3). The warming trend is positive for the Mestia weather station, the lowest elevation location (Fig. 5), although it is only statistically significant for the period 1961-2013 (Table 4). Mean monthly temperatures were warmer compared with the earlier period 1906-1960 in the autumn/winter (October-April), but cooler in spring/summer (May-September).

During 1906-2013 just 2 years - 1966 (for all meteorological stations) and 1993 (just for Mestia) were abnormally warm and 1 single year (1983) was very cold for Kazbegi. Mestia's 1993 warm temperature caused unusually high December mean temperature $\left(3.6^{\circ} \mathrm{C}\right)$, compared to the mean multiannual December temperature $\left(-3.7^{\circ} \mathrm{C}\right)$. In January 1983 , the absolute minimum temperature $\left(-42^{\circ} \mathrm{C}\right)$ was recorded in Georgia, at Kazbegi station, where the January mean temperature was $-22.4^{\circ} \mathrm{C}$, compared to the mean multiannual January temperature $\left(-14.4^{\circ} \mathrm{C}\right)$.

An increase in the accumulation season (October-April) precipitation similar to that found by Shahgedanova et al. (2014), and statistically significant at $95 \%$ confidence level, was registered at both Mestia and Mamisoni meteorological stations in their most recent 1985-2010 and 1981-1993 periods, when average precipitation of 608.5 and $527.1 \mathrm{~mm}$ exceeded their 1961-1985 and 1965-1980 averages of 495.7 and $380.0 \mathrm{~mm}$ by 22.7 and $38.7 \%$, respectively, (Fig. 6). By contrast, the accumulation season precip- 
Table 3. Mean monthly air temperatures $\left({ }^{\circ} \mathrm{C}\right)$ at the Mestia, Mamisoni, Jvari Pass and Kazbegi meteorological stations in the years of 1906/1907-1960 and 1961-2009/2013.

\begin{tabular}{lcrrrrrrrrrrrrr}
\hline $\begin{array}{l}\text { Meteo } \\
\text { station }\end{array}$ & $\begin{array}{c}\text { Year/ } \\
\text { month }\end{array}$ & 1 & 2 & 3 & 4 & 5 & 6 & 7 & 8 & 9 & 10 & 11 & 12 & $\begin{array}{r}\text { Mean } \\
\text { annual }\end{array}$ \\
\hline Mestia & $1906-1960$ & -5.7 & -4.6 & -0.5 & 5.4 & 10.9 & 14.1 & 16.6 & 16.5 & 12.3 & 7.1 & 2.0 & -3.8 & 5.9 \\
Mestia & $1961-2013$ & -5.5 & -3.8 & 0.1 & 5.9 & 10.8 & 13.8 & 16.6 & 16.3 & 12.0 & 7.2 & 1.5 & -3.7 & 6.0 \\
Mamisoni & $1907-1960$ & -11.6 & -11.6 & -9.0 & -3.8 & 0.9 & 4.2 & 7.8 & 7.8 & 4.2 & -0.6 & -5.1 & -9.1 & -2.2 \\
Mamisoni & $1961-1995$ & -9.8 & -11.1 & -10.0 & -7.5 & -3.1 & 1.4 & 5.0 & 6.8 & 6.6 & 2.9 & -1.6 & -5.9 & -2.2 \\
Jvari Pass & $1907-1960$ & -10.5 & -10.3 & -7.4 & -1.5 & 3.3 & 7.4 & 10.4 & 10.3 & 6.6 & 1.8 & -3.3 & -7.8 & -0.1 \\
Jvari Pass & $1961-2009$ & -10.4 & -9.8 & -6.6 & -0.9 & 3.4 & 7.6 & 10.8 & 10.3 & 6.8 & 2.0 & -3.1 & -7.9 & 0.2 \\
Kazbegi & $1907-1960$ & -14.5 & -14.7 & -12.3 & -7.7 & -3.4 & -0.1 & 3.2 & 3.6 & 0.2 & -4.0 & -8.3 & -12.2 & -5.8 \\
Kazbegi & $1961-2009$ & -14.4 & -14.3 & -11.9 & -7.5 & -3.1 & 0.3 & 3.5 & 3.8 & 0.3 & -3.8 & -8.0 & -12.1 & -5.6 \\
\hline
\end{tabular}
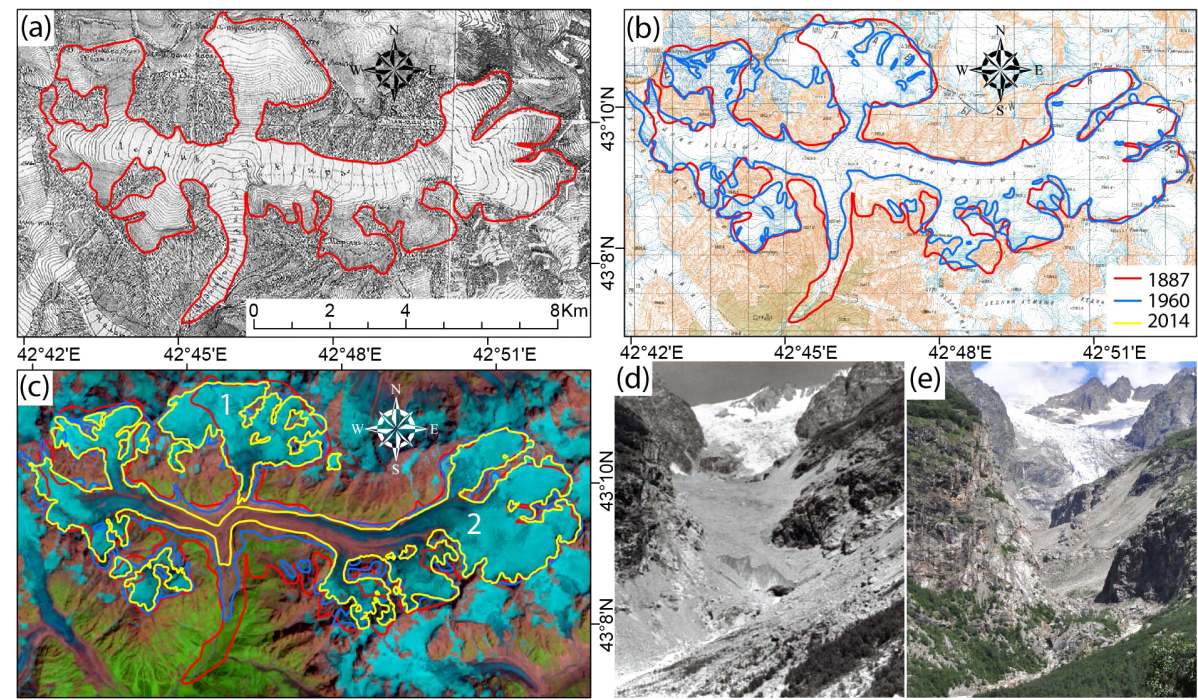

Figure 4. (a) Lekhziri Glacier, topographical map 1887; (b) topographical map 1960, (c) Landsat L8 imagery; 1: northern Lekhziri (central flow), 2: Georgia's largest glacier Lekhziri (consisting of two flows); (d) Lekhzi Glacier terminus in 1960 (photo by Sh. Inashvili); (e) the same view in 2011 (photo by L. G. Tielidze).

itation increased by only $3.6 \%$ at Jvari Pass in 1981-1990 $(677.9 \mathrm{~mm})$ in comparison with $1965-1980(653.6 \mathrm{~mm})$.

\section{Discussion}

The modest annual temperature increase over the last century in the Georgian Caucasus is lower than in many regions, for example, in the Alps, where over the 20th century temperatures have risen by about $2{ }^{\circ} \mathrm{C}$ at a rate about twice as large as the northern-hemispheric average (Auer et al., 2007). This observed warming was relatively homogeneous over the Alpine region but was particularly pronounced from 1980 onwards with annual mean warming rates of about $0.5^{\circ} \mathrm{C}$ per decade (EEA, 2009; Gobiet et al., 2014). The response time of a glacier to a change in climate depends on its size, attributes, and topography (Tennant et al., 2012), and is not immediate. However, it appears that the Alpine glaciers average annual retreat rate over the last half century is about twice that of Georgian Caucasus glaciers (Fischer et al., 2014).

My analysis shows that the RGI 4.0 and 5.0 version databases contain some errors, especially in the central Caucasus section. For example in the Samegrelo sub-range, the RGI databases contain 9 glaciers with a total area of $2.8 \mathrm{~km}^{2}$. In my database there are 22 glaciers, with a total area of $1.4 \mathrm{~km}^{2}$. The Lechkhumi and Shoda-Kedela sub-ranges, where the RGI databases contain 31 glaciers, have a total area of $37.5 \mathrm{~km}^{2}$; nevertheless I found just 6 glaciers with a total area of $0.9 \mathrm{~km}^{2}$. In the GLIMS database, the opposite has occurred as smaller glaciers have been omitted in the Samegrelo, Lechkhumi, Shoda-Kedela sub-ranges (central Caucasus section) - missing 28 glaciers, with area of $2.3 \mathrm{~km}^{2}$, and the Tergi, Asa, Arghuni and Pirikita Alazani river basins (eastern Caucasus section) - missing 42 glaciers, with area of $6.0 \mathrm{~km}^{2}$, resulting in lower glacier numbers and mapped glacierized area. 


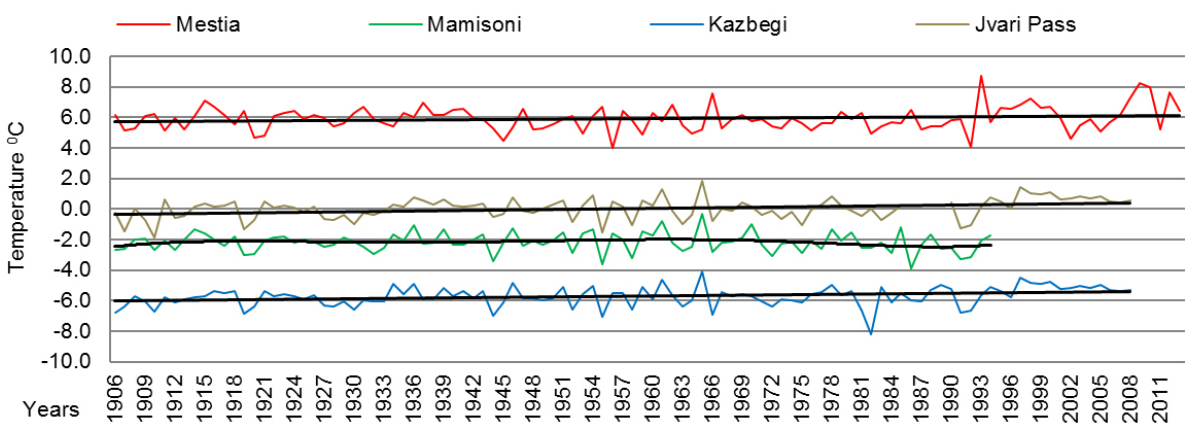

Figure 5. Mean annual air temperatures at the Mestia, Mamisoni, Jvari Pass and Kazbegi meteorological stations over the last century. The black line is the trend showing a temperature course with time.

Table 4. Results of the Mann-Kendall test for temperature data for the weather stations of Georgia in the years of (1907-2009)-(19071960)-(1961-2009). Statistically significant results are in bold.

\begin{tabular}{lrrrrr}
\hline $\begin{array}{l}\text { Meteo } \\
\text { stations }\end{array}$ & $\begin{array}{r}\text { Mann Kendall } \\
\text { statistic }(S)\end{array}$ & $\begin{array}{r}\text { Kendall's } \\
\tau\end{array}$ & $\begin{array}{r}\text { Var } \\
(S)\end{array}$ & $\begin{array}{c}p \text { value } \\
\text { (one-tailed) }\end{array}$ & $\alpha$ \\
\hline \multicolumn{7}{c}{ Mann-Kendall test (1907-2009) } \\
\hline Jvari pass & 1042 & 0.1984 & 123151 & 0.0015 & 0.05 \\
Kazbegi & 1242 & 0.2365 & 123147 & 0.0002 & 0.05 \\
Mamisoni & -174 & -0.0444 & 79625 & 0.7301 & 0.05 \\
Mestia & 302 & 0.0533 & 137993 & 0.2089 & 0.05 \\
\hline \multicolumn{7}{c}{ Mann-Kendall test (1907-1960) } \\
\hline Jvari pass & 256 & 0.1790 & 17965 & 0.0286 & 0.05 \\
Kazbegi & 228 & 0.1594 & 17966 & 0.0452 & 0.05 \\
Mamisoni & 109 & 0.0762 & 17967 & 0.2102 & 0.05 \\
Mestia & -44 & -0.0308 & 17966 & 0.6258 & 0.05 \\
\hline \multicolumn{7}{c}{ Mann-Kendall test (1961-2009) } \\
\hline Jvari pass & 342 & 0.2908 & 13458 & 0.0016 & 0.05 \\
Kazbegi & 321 & 0.2731 & 13457 & 0.0029 & 0.05 \\
Mamisoni pass & -85 & -0.1429 & 4958 & 0.8835 & 0.05 \\
Mestia & 288 & 0.2090 & 16995 & 0.0139 & 0.05 \\
\hline
\end{tabular}

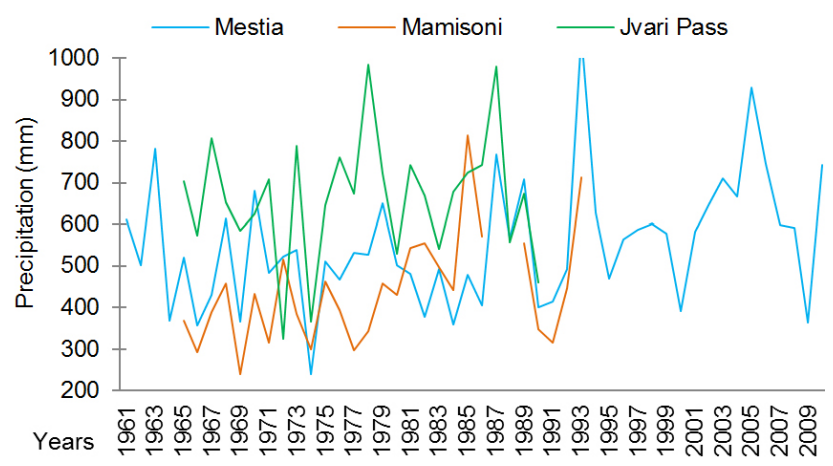

Figure 6. October-April precipitation for Mestia (1961-2010), Mamisoni (1965-1993) and Jvari Pass (1965-1990) meteorological stations.
In 1960-2014 the reduction in glacier area in Georgia was mostly caused by the disappearance of small cirque glaciers $\left(\leq 1.0 \mathrm{~km}^{2}\right)$ which were predominant in $1960-70$, in association with a modest warming temperature trend. Between 1960 and 2014 glacier area and numbers decreased least in the western Caucasus. This results from more precipitation falling there as winter snow (in the Abkhazeti sector) compared to the central and eastern Caucasus (Kordzakhia, 1967; Gobejishvili, 1995). Thus glacier area $\left(0.6 \mathrm{~km}^{2}\right.$ average area) in the Bzipi River basin (western Caucasus) decreased 59.6 $\pm 2.7 \%$ between 1960 and 2014, but glacier numbers were unchanged. This was also observed in the Canadian Rocky mountains where small cirque glaciers $\left(0.5 \mathrm{~km}^{2}\right)$ decreased only in size by $52 \%$ between 1881 and 1991 (Lawby et al., 1995). The greater glacier melt in the eastern Caucasus is conditioned not only by climate, but also by the morphological peculiarities of the relief. Some of the 
river basins are built on Jurassic sedimentary rocks, which suffer consistent denudation, detrimental to glacier preservation (Gobejishvili et al., 2011).

Between 1911 and 2014, the highest percentage glacier loss from Georgia's four largest river basins (Enguri, Rioni, Kodori and Tergi) was observed in the Tergi River basin, where glacier area decreased by $60.1 \pm 1.7 \%$ $\left(0.6 \pm 0.01 \% \mathrm{yr}^{-1}\right)$. The glacier area in the Rioni River basin in 1911-1960 was reduced by only $2.5 \pm 2.1 \%$ and the Enguri River basin glaciers by $2.8 \pm 1.6 \%$. This reflects the deficiencies in the 1911 catalog data, but source represents the only available data for this period for future comparison of the Caucasus glaciers.

I compared my results to those of Shahgedanova et al. (2014) for the northern slopes, where the most heavily debris-covered glacier was Donguz-Orun $\left(43.231^{\circ} \mathrm{N}\right.$, $42.512^{\circ} \mathrm{E}$ ) and supra-glacial debris covers approximately $70 \%$. Generally in the Caucasus, south facing glaciers are characterized by less debris cover then those with northern aspects.

Direct comparisons with other inventories in the Caucasus are difficult, because most of them cover relatively short and recent periods. However, my results are consistent with other studies of glacier change in the Caucasus Mountains. For example, Shahgedanova et al. (2014), suggest that glaciers located on the southern slopes of the central Caucasus range may have lost a higher proportion of their area than glaciers in northern regions of the Caucasus $\left(5.6 \pm 2.5 \mathrm{~km}^{2}\right)$ between 2000 and the 2010-2012 period. The valley glaciers lost an even higher proportion (7.4\%). Khromova et al. (2014) mapped outlines of 179 glaciers, of which 108 glaciers are located on the northern slopes of the Greater Caucasus while 71 are located on the southern slopes. They found that glaciers lost $4.9 \%$ of their area between 2001 and 2010. Glacier wastage was higher in the southern slopes at $5.6 \%$ vs. $4.3 \%$ in the northern slopes glaciers.

Glacier reduction in the Caucasus Mountains appears to be slower than some regions such as the European Alps. Fischer et al. (2014) reported $33 \%\left(1.1 \% \mathrm{yr}^{-1}\right)$ and $11 \%$ $\left(1.3 \% \mathrm{yr}^{-1}\right)$ reduction for the eastern Swiss Alps for the 1973-2003 and 2003-2009 periods, respectively; but it appears to be faster than in the Altai mountains, where Khromova et al. (2014) reported $16.4 \%\left(0.3 \% \mathrm{yr}^{-1}\right)$ glacier area loss between 1952 and 2004. Sorg et al. (2012) reported average glacier ice loss of $0.3 \% \mathrm{a}^{-1}$ in Tien Shan over the last half century. The strongest annual area shrinkage rates were found in the outer ranges $\left(0.4\right.$ to $\left.0.8 \% \mathrm{a}^{-1}\right)$, whereas smaller rates were reported for glaciers in the inner $\left(0.2\right.$ to $\left.0.4 \% \mathrm{a}^{-1}\right)$ and eastern ranges $\left(0.1\right.$ to $\left.0.3 \% \mathrm{a}^{-1}\right)$. The overall range of annual area changes was similar to those for the HimalayaKarakorum region, which represent the southern margin of the Asian high mountains complex ( 0.1 to $0.7 \% \mathrm{a}^{-1}$ ) (Bolch et al., 2012). The Georgian Caucasus inventory data parallels results in the Canadian Rocky Mountains, where Tennant et al. (2012) reported $40 \pm 5 \%\left(0.5 \pm 0.06 \% \mathrm{yr}^{-1}\right)$ glacier area loss between 1919 and 2006, and in the Cordillera Blanca mountains (Peru), where Racoviteanu et al. (2008) estimated overall loss in glacierized area of $22.4 \%\left(0.7 \% \mathrm{yr}^{-1}\right)$ from 1970 to 2003.

\section{Conclusions}

I used Podozerskiy's 1911 catalog, 1960 maps data and recent (2014) Landsat and ASTER imagery to determine area change of glaciers in the Georgian Caucasus mountains. The main uncertainties and errors arise from 1911 data quality, specifically glacier firn area extent boundaries. Despite these errors, the 1911 Podozerskiy's catalog is still a useful source of information on early 20th century glacier extents and elevations. Over long periods, glacier changes are significantly larger than the errors in the maps. Other sources of error in the most recent data sets include debris cover, which hinder glacier delineation, but by using GPS field data these can be resolved.

The Georgian Caucasus region experienced glacier area loss over the last century at an average annual rate of $0.4 \%$ with a higher rate in eastern Caucasus than in the central and western sections. Glacier melt is faster for southern glaciers than northern glaciers. A combination of topographic factors including glacier geometry and elevation, as well as climatic aspects such as southern aspect and higher radiation input, are related to the observed spatial trends in the glacier change analysis. Extending the attributes considered in this study, future research should further focus on attributes related to glacier type and source of nourishment (e.g. outlet, cirque, avalanche-fed and debris-covered glaciers), in order to better understand how these factors influence glacier change.

Acknowledgements. I gratefully acknowledge the financial support by the Shota Rustaveli Georgian National Science Foundation project "Glaciological Catalogue of Georgia" (AR/151/9-102/13). Special thanks to the editor Tobias Bolch for detailed comments which helped to improve the paper. Two reviewers provided useful suggestions and comments which clearly enhanced the quality of the paper. Special thanks to my supervisor Roger Wheate from UNBC, who strongly improved the manuscript by correcting the language and identifying scientific inconsistencies. I thank Nino Chikhradze and Nino Lomidze for cooperation during the preparation of the paper.

Edited by: T. Bolch 


\section{References}

Arendt, A. A., Bliss, A., Bolch, T., and 85 others: Randolph Glacier Inventory - A Dataset of Global Glacier Outlines: Version 5.0. GLIMS Technical Report, National Snow and Ice Data Center, Boulder, USA, 2015.

Auer, I., Bohm, R., Jurkovic, A., Lipa, W., Orlik, A., Potzmann, R., Schoner, W., Ungersbock, M., Matulla, C., Briffa, K., Jones, P., Efthymiadis, D., Brunetti, M., Nanni, T., Maugeri, M., Mercalli, L., Mestre, O., Moisselin, J., Begert, M., Muller-Westermeier, G., Kveton, V., Bochnicek, O., Stastny, P., Lapin, M., Szalai, S., Szentimrey, T., Cegnar, T., Dolinar, M., Gajic-Capka, M., Zaninovic, K., Majstorovicp, Z., and Nieplovaq, E.: HISTALPhistorical instrumental climatological surface time series of the Greater Alpine Region, Int J. Climatol., 27, 17-46, 2007.

Begert, M., Schlegel, T., and Kirchhofer, W.: Homogeneous Temperature And Precipitation Series of Switzerland from 1864 to 2000, Int. J. Climatol., 25, 65-80, 2005.

Beniston, M.: Climatic change in mountain regions: a review of possible impacts, Climatic Change, 59, 5-31, 2003.

Bhambri, R., Bolch, T., Chaujar, R. K., and Kulshreshtha, S. C.: Glacier changes in the Garhwal Himalaya, India, from 1968 to 2006 based on remote sensing, J. Glaciol., 57, 543-556, 2011.

Bolch, T., Buchroithner, M. F., Pieczonka, T., and Kunert, A.: Planimetric and volumetric glacier changes in the Khumbu Himalaya 1962-2005 using Corona and ASTER data, J. Glaciol., 54, 562-600, 2008.

Bolch, T., Menounos, B., and Wheate, R.: Landsat-based inventory of glaciers in western Canada, 1985-2005, Remote Sens. Environ., 114, 127-137, doi:10.1016/j.rse.2009.08.015, 2010.

Bolch, T., Kulkarni, A., Kääb, A., Huggel, C., Paul, F., Cogley, G., Frey, H., Kargel, J., Fujita, K., Scheel, M., Bajracharya, S., and Stoffel, M.: The state and fate of Himalayan glaciers, Science, 336, 310-314, doi:10.1126/science.1215828, 2012.

Catalog of Glaciers of the USSR: Katalog Lednitov USSR, vol. 8-9, Gidrometeoizdat, Leningrad, 108 pp., 1975.

Cogley, J. G.: A more complete version of the World Glacier Inventory, Ann. Glaciol., 50, 32-38, 2009.

Earl, L. and Gardner, A.: satellite-derived glacier inventory for North Asia, Ann. Glaciol., 57, 50-60, doi:10.3189/2016AoG71A008, 2016.

EEA - European Environment Agency: Regional climate change and adaptation: the Alps facing the challenge of changing water resources, EEA report 8, Copenhagen, Denmark, 143 pp., 2009.

Fischer, M., Huss, M., Barboux, C., and Hoelzle, M.: The new Swiss Glacier Inventory SGI2010: Relevance of using high resolution source data in areas dominated by very small glaciers, Arct. Antarct. Alp. Res., 46, 933-945, 2014.

Gobejishvili, R. G.: Ledniki Gruzii (Glaciers of Georgia), Monograph. Publ. "Metsniereba", Tbilisi, 148 pp., 1989.

Gobejishvili, R. G.: Saqartvelos tanamedrove mkinvarebi da Evraziis mtebshi gamkinvarebis evolucia gvian Pleistocensa da Holocenshi (Present day glaciers of Georgia and evolution of glaciation in the mountains of Eurasia in late Pleistocene and Holocene), sadoqtoro disertacia, Tbilisi, 320 pp., 1995.

Gobejishvili, R., Lomidze, N., and Tielidze, L.: Late Pleistocene (Wurmian) glaciations of the Caucasus, in: Quaternary Glaciations: Extent and Chronology, edited by: Ehlers, J., Gibbard, P. L., and Hughes, P. D., Elsevier, Amsterdam, 141-147, doi:10.1016/B978-0-444-53447-7.00012-X, 2011.
Gobiet, A., Kotlarski, S., Beniston, M., Heinrich, G., Rajczak, J., and Stoffel, M.: 21st century climate change in the European Alps - A review, Sci. Total Environ., 493, 1138-1151, 2014.

Granshaw, F. D. and Fountain, A. G.: Glacier change (1958-1998) in the North Cascades National Park Complex, Washington, USA, J. Glaciol., 52, 251-256, doi:10.3189/172756506781828782, 2006.

Guo, W., Liu, S., Xu, J., Wu, L., Shangguan, D., Yao, Xi., Wei, J., Bao, W., Yu, P., Liu, Q., and Jiang, Z.: The second Chinese glacier inventory: data, methods and results, J. Glaciol., 61, 357372, doi:10.3189/2015JoG14J209, 2015.

Horvath, E. and Field, W. O.: The Caucasus, in: Mountain Glaciers of the Northern Hemisphere, edited by: Field, W. O., Cold Regions Research and Engineering Laboratory, Hanover, NH, 343359, 1975.

Kaab, A.: Monitoring high-mountain terrain deformation from repeated air- and spaceborne optical data: examples using digital aerial imagery and ASTER data, ISPRS J. Photogramm., 57, 3952, 2002.

Khromova, T., Nosenko, G., Kutuzov, S., Muravievand, A., and Chernova, L.: Glacier area changes in Northern Eurasia, Environ. Res. Lett., 9, 015003, doi:10.1088/1748-9326/9/1/015003, 2014.

Kordzakhia, R.: Mdinareebis Enguris da Tskhenistskhlis auzebis klimaturi maxasiateblebi Svanetis farglebshi (Enguri and Tskhenistskhali river basins climate features within the Svaneti), Saqartvelos geografiuli sazogadoebis shromebi, Vol. IX-X, Tbilisi, 110-125, 1967.

Kotlyakov, V. M., Dyakova, A. M., Koryakin, V. S., Kravtsova, V. I., Osipova, G. B., Varnakova, G. M., Vinogradov, V. N., Vinogradov, O. N., and Zverkova, N. M.: Glaciers of the former Soviet Union, in: Satellite image atlas of glaciers of the world Glaciers of Asia, edited by: Williams Jr., R. S. and Ferrigno, J. G., US Geological Survey Professional Paper 1386-F-1, US Geological Survey, Washington, USA, 4-5, 2010.

Lawby, C. P., Smith, D. J., Laroque, C. P., and Brugman, M. M.: Glaciological studies at Rae Glacier, Canadian Rocky mountains, Phys. Geogr., 15, 425-441, 1995.

Maruashvili, L.: Saqartvelos fizikuri geografia (Physical Geography of Georgia), Monograph. Publ. "Metsniereba", Tbilisi, 1971.

Meier, M. F., Dyurgerov, M. B., Rick, U. K., O’Neel, S., Pfeffer, W. T., Anderson, R. S., Anderson, S. P., and Glazovsky, A. F.: Glaciers dominate eustatic sea-level rise in the 21 st century, Science, 317, 1064-1067, doi:10.1126/science.1143906, 2007.

Oerlemans, J. and Fortuin, J. P. F.: Sensitivity of glaciers and small ice caps to greenhouse warming, Science, 258, 115-117, doi:10.1126/science.258.5079.115, 1992.

Paul, F. R., Barry, R. G., Cogley, J. G., Frey, H., Haeberli, W., Ohmura, A., Ommanney, C. S. L., Raup, B., Rivera, A., and Zemp, M.: Recommendations for the compilation of glacier inventory data from digital sources, Ann. Glaciol., 50, 119-126, 2009.

Pfeffer, W. T., Arendt, A. A., Bliss, A., Bolch, T., Cogley, J. G., Gardner, A. S., Hagen, J., Hock, R., Kaser, G., Kienholz, C., Miles, E. S., Moholdt, G., Mölg, N., Paul, F., Radic V., Rastner, P., Raup, B. H., Rich, J., Sharp, M. J., and The Randolph Consortium: The Randolph Glacier Inventory: a globally complete inventory of glaciers, J. Glaciol., 60, 537-552, doi:10.3189/2014JoG13J176, 2014. 
Podozerskiy, K. I.: Ledniki Kavkazskogo Khrebta (Glaciers of the Caucasus Range): Zapiski Kavkazskogo otdela Russkogo Geograficheskogo Obshchestva, Publ. Zap. KORGO., Tiflis, 29, 1, 200 pp., 1911.

Racoviteanu, A. E., Arnaud, Y., Williams, M. W., and Ordonez, J.: Decadal changes in glacier parameters in the Cordillera Blanca, Peru, derived from remote sensing, J. Glaciol., 54, 499-510, doi:10.3189/002214308785836922, 2008.

Raup, B., Kaab, A., Kargel, J., Bishop, M. P., Hamilton, G. S., Lee, E., Rau, F., Paul, F., Soltesz, D., Singh Kalsa, S. J., Beedle, M., and Helm, C.: Remote Sensing and GIS technology in the Global Land Ice Measurements from Space (GLIMS) Project, Comput. Geosci., 33, 104-125, 2007.

Reinhardt, A. L.: Snejnaya granica Kavkaze (The snow line in the Caucasus), Izvestia Kavkazskogo otdela Imperatorskogo Russkogo Geograficheskogo Obshchestva, T. 24. Vol. 3, 1916.

Shahgedanova, M., Nosenko, G., Kutuzov, S., Rototaeva, O., and Khromova, T.: Deglaciation of the Caucasus Mountains, Russia/Georgia, in the 21 st century observed with ASTER satellite imagery and aerial photography, The Cryosphere, 8, 2367-2379, doi:10.5194/tc-8-2367-2014, 2014.

Sorg, A., Bolch, T., Stoffel, M., Solomina, O., and Beniston, M.: Climate change impacts on glaciers and runoff in Tien Shan (Central Asia), Nat. Clim. Change, 2, 725-731, doi:10.1038/nclimate1592, 2012.

Stokes, C. R., Gurney, S. D., Popovnin, V., and Shahgedanova M.: Late-20th-century changes in glacier extent in the Caucasus Mountains, Russia/Georgia, J. Glaciol., 52, 99-109, 2006.

Stokes, C. R.: Sections: Caucasus mountains, in: Encyclopedia of snow, ice and glaciers, Springer, Dordrecht, the Netherlands, 803-808, 2011.
Stokes, C. R., Popovnin, V. V., Aleynikov, A., and Shahgedanova, M.: Recent glacier retreat in the Caucasus Mountains, Russia, and associated changes in supraglacial debris cover and supra/proglacial lake development, Ann. Glaciol., 46, 196-203, 2007.

Tennant, C., Menounos, B., Wheate, R., and Clague, J. J.: Area change of glaciers in the Canadian Rocky Mountains, 1919 to 2006, The Cryosphere, 6, 1-12, doi:10.5194/tc-6-1-2012, 2012.

Tielidze, L. G.: Saqartvelos Mkinvarebi (Glaciers of Georgia), Monograph. Publ. "Color", 254 pp., Tbilisi, 2014.

Tielidze, L. G.: Modern and old glaciers of Georgia, Monograph. Publ. "Samshoblo", 216 pp., Tbilisi, 2016.

Tielidze, L. G., Chikhradze, N., and Svanadze, D., Glaciers Amount and Extent Change in the Dolra River Basin in 1911-1960-2014 Years, Caucasus Mountains, Georgia, Observed with Old Topographical Maps and Landsat Satellite Imagery, Am. J. Clim. Change, 4, 217-225, doi:10.4236/ajcc.2015.43017, 2015a.

Tielidze, L. G., Kumladze, R., and Asanidze, L.: Glaciers reduction and climate change impact over the last one century in the Mulkhura River Basin, Caucasus Mountains, Georgia, Int. J. Geosci., 6, 465-472, doi:10.4236/ijg.2015.65036, 2015 b.

Tielidze, L. G., Lomidze, N., and Asanidze, L.: Glaciers retreat and climate change effect during the last one century in the Mestiachala River Basin, Caucasus Mountains, Georgia, Earth Sci., 4, 72-79, doi:10.11648/j.earth.20150402.12, $2015 \mathrm{c}$.

Volodicheva, N.: The Caucasus, in: The physical geography of Northern Eurasia, edited by: Shahgedanova, M., Oxford University Press, Oxford, 350-376, 2002. 